\title{
Efficiency Evaluation and Usages of Thunbergia alata, Thunbergia erecta and their Combination
}

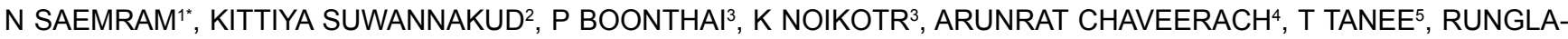
WAN SUDMOON ${ }^{6}$ AND P SIRIPIYASING ${ }^{7}$

${ }^{1}$ Department of Chemistry, Faculty of Science, Ramkhamhaeng University, Bangkok 10240, 2Department of Biology, Faculty of Science, Bansomdejchaopraya Rajabhat University, Bangkok 10240, ${ }^{3}$ Department of Biology, Faculty of Science, Ramkhamhaeng University, Bangkok 10240, “'Department of Biology, Faculty of Science, Khon Kaen University, Khon Kaen 40002, ${ }^{5}$ Faculty of Environment and Resource Studies, Mahasarakham University, Maha Sarakham 44150, ${ }^{6}$ Faculty of Law, Khon Kaen University, Khon Kaen 40002, ${ }^{7}$ Faculty of Science and Technology, Mahasarakham Rajabhat University, Maha Sarakham 44150, Thailand
\end{abstract}

\section{Saemram et al.: Efficiency Evaluation of Thunbergia alata and Thunbergia erecta}

\begin{abstract}
Thunbergia alata and Thunbergia erecta have been mostly used for ornamentation but have interesting other uses. However, toxicity and phytochemical studies of these plants are lacking. Therefore, phytochemicals of the two species were investigated by gas chromatography-mass spectrometry, cytotoxicity and genotoxicity were tested via 3-(4,5-dimethylthiazol-2yl)-2,5-diphenyltetrazolium bromide and comet assays in normal human peripheral blood mononuclear cells. Then, the extracts of the two species and their combination were applied to peripheral blood mononuclear cells poisoned with rice whisky and bathroom cleaner as toxic models in everyday life. The results showed that the major phytochemicals were $12.36 \%$ and $24.90 \%$ phytol in ethanol extracts of Thunbergia alata and Thunbergia erecta and $46.29 \%$ and 43.47 $\%$ oleamide in hexane extracts of Thunbergia alata and Thunbergia erecta, respectively. Half-maximal inhibitory concentration values, which indicate toxicity in cells, were not detected for either species, but at the deoxyribonucleic acid level, the extracts induced significant deoxyribonucleic acid damage, shown by high Olive Tail Moment values in peripheral blood mononuclear cells $(\mathbf{p}<0.05)$. Biological activity of the extracts revealed by higher cell viability percentages and lower Olive Tail Moment values in the treatments (poisoned peripheral blood mononuclear cells treated with plant extracts) than the controls (poisoned peripheral blood mononuclear cells). Taking all the results together, Thunbergia alata and Thunbergia erecta extracts and their combination can be applied for many benefits in humans following properties that have been previously used and their phytochemicals but have limitations of doses.
\end{abstract}

Key words: Biological activity, comet assay, gas chromatography-mass spectrometry, 3-(4,5-dimethylthiazol2-yl)-2,5-diphenyl tetrazolium bromide assay, oleamide, phytol

Plants of the genus Thunbergia are well known in several species for medicine and ornamentation, but not for foods such as T. laurifolia, T. grandiflora, T. alata, T. erecta, $T$. coccinea, $T$. colpifera and $T$. fragrans. Of all of them, $T$. laurifolia was the first widely consumed both in traditionally and locally prepared forms for human living and the second species used was $T$. grandifola. Many ethnobotanical reviews and scientific publications have pointed to the indications, phytochemicals and treatments of these two species. Various compounds isolated from the leaves of T. laurifolia include iridoid glycoside, grandifloric acid, glucopyranosides and derivatives of apigenin, delphinidin and phenolic acids: chlorogenic, caffeic,

*Address for correspondence E-mail: naphatra22@gmail.com gallic and protocatechuic. These substances give the plant various effects as follows: biological effects and applications as an antidote for poisons and drugs and in treating drug addiction. The plant has also been reported to have antioxidant, antidiabetic, anti-inflammatory, antipyretic, antimicrobial and hepatoprotective properties $^{[1,2]}$. Additionally, T. laurifolia has reduced heavy metal on lead-induced acetylcholinesterase

\footnotetext{
This is an open access article distributed under the terms of the Creative Commons Attribution-NonCommercial-ShareAlike 3.0 License, which allows others to remix, tweak, and build upon the work non-commercially, as long as the author is credited and the new creations are licensed under the identical terms
}

Accepted 02 June 2021 Revised 26 August 2020

Received 11 February 2020 Indian J Pharm Sci 2021;83(3):494-503 
dysfunction and cognitive impairment in mice ${ }^{[3]}$, reduced signs of toxicity and reduced organ damage caused by cadmium $^{[4]}$. Toxicity has also been reported. Chivapat et al. ${ }^{[5]}$ studied chronic toxicity of T. laurifolia in rats for 6 mo, which did not produce any histological alterations of visceral organs in any rat group. Another one of the species mentioned, $T$. grandiflora was shown to have activity and vital phytochemicals, including phenols and flavonoids. Its leaves had potential antioxidative and anticholinesterase inhibitory effects, which may be effective in treating Alzheimer's disease ${ }^{[6]}$. In addition, T. grandiflora leaves had marked hypoglycemic and antioxidant activity and hepatoprotective effects in liver-damaged rats ${ }^{[7]}$. There are few scientific studies on T. alata and T. erecta. Methanol extracts of T. alata play an important inhibitory role in the modulation of severe inflammation ${ }^{[8]}$. Three phenolic compounds, caffeoylmalic, feruloylmalic and p-coumaroylmalic acids, were found in the leaves of T. alata; their concentrations were different during wounding and salicylic acid treatment and were elicited by salicylic $\operatorname{acid}^{[9]}$. The flower of $T$. erecta L. can be used as an alternative to commercial indicators and is more environmentally friendly ${ }^{[10]}$. T. erecta, including leaves, stems, roots and flowers, could be exploited for the green synthesis of zinc oxide nanoparticles, which can be used in the development of pharmaceutical products beneficial to mankind ${ }^{[11]}$. Bhuiyan et al. ${ }^{[12]}$ researched T. erecta, a medicinal plant with many reported phytochemicals and significant medicinal value and revealed that the methanol leaf extract has hypoglycemic effects in an animal model. The most recent research reported experimental results in swiss albino mice with $T$. erecta, which contained phytoconstituents, flavonoids, glycosides, tannins saponin, carbohydrates and alkaloids and possessed sedative and anxiolytic activity traditionally used in insomnia, depression and anxiety management ${ }^{[13]}$. Information on the two wellknown, representative species of Thunbergia mentioned above, T. laurifolia and T. grandiflora, is very important for natural methods for human health, which is a longlived concept. There are more interesting species in the Thunbergia genus that should be focused on for their benefits to human health as a natural way to decrease public health costs and disease suffering.

This research aimed to evaluate the biological efficacy, usage and limitations of $T$. alata and $T$. erecta following phytochemicals, toxicity and biological activity testing. Additionally, the combined extract of the two species was tested to confirm the enhanced efficacy in poisoned peripheral blood mononuclear cells (PBMCs).

\section{MATERIALS AND METHODS}

Leaves of the two studied plant species, T. alata and $T$. erecta were collected for the following tests: phytochemical analyses via gas chromatographymass spectrometry (GC-MS), cytotoxicity and genotoxicity testing via 3-(4,5-dimethylthiazol-2yl)2,5-diphenyltetrazolium bromide (MTT) and comet assays. The biological activity of the plants was tested in PBMCs poisoned with bathroom cleaner (containing $8.5 \% \mathrm{w} / \mathrm{w}$ hydrochloric acid and $2 \% \mathrm{w} / \mathrm{w}$ ethoxylated alcohol) and rice whisky (containing $40 \%$ alcohol).

Phytochemical extraction, extract component analysis via GC-MS, isolation of human PBMCs, cell toxicity testing by MTT assay and genotoxicity testing by comet assays were performed following Sirikhansaen et al. ${ }^{[14]}$ and briefly described below.

\section{Phytochemical composition analysis:}

Dried powder of the sample was macerated in hexane or ethanol, $20 \mathrm{~g}$ to $100 \mathrm{ml}$, for $72 \mathrm{~h}$ and then filtered. The filtrates were analyzed by an Agilent Technologies GC $6890 \mathrm{~N} / 5973$. The relative percentage of the constituents was expressed and determined.

\section{Extract preparation for toxicity testing:}

Solvents were evaporated from the filtrates by rotary evaporation, then the dried filtrates were redissolved in dimethyl sulfoxide (DMSO) and maintained as stock extracts at $-20^{\circ}$.

\section{Isolation of human peripheral blood mononuclear cells (PBMCs):}

Anonymous buffy coat samples were received from a blood bank and used for PBMCs isolation using FicollPaque Plus (GE Healthcare). The isolated cells were suspended at a concentration of $10^{6}$ cell $/ \mathrm{ml}$ in modified RPMI-1640 medium, with $2 \mathrm{mM}$ L-glutamine and $25 \mathrm{mM}$ 4-(2-hydroxyethyl)-1-piperazineethanesulfonic acid (HEPES), supplemented with $10 \%$ Fetal bovine serum (FBS) , $5 \mu \mathrm{g} / \mathrm{ml}$ phytohemagglutinin (PHA), $100 \mu \mathrm{g} / \mathrm{ml}$ streptomycin and $100 \mathrm{U} / \mathrm{ml}$ penicillin.

\section{MTT assay:}

The stock extracts were serial 10-fold diluted with water, for five levels as working concentrations. The prepared cells were seeded in 96-well plates, $125 \mu \mathrm{l}$ per well, $12.5 \mu \mathrm{l}$ of the extract working concentrations were added to each well, the untreated cells and the cells treated with UV light for 20 min were used as negative 
and positive controls, respectively. The plates were incubated for $4 \mathrm{~h}$ at $37^{\circ}$ with $5 \% \mathrm{CO}_{2}$. The medium was removed and then $10 \mu \mathrm{l}$ of $0.5 \mathrm{mg} / \mathrm{ml}$ MTT (Sigma, USA) was added to each well, the plates were incubated for $4 \mathrm{~h}$ at $37^{\circ}$, in the dark. DMSO was added to each well to solubilize formazan crystals for $4 \mathrm{~h}$ in the dark; finally, the absorbance was read at $570 \mathrm{~nm}$. If the Halfmaximal inhibitory concentration $\left(\mathrm{IC}_{50}\right)$ values were observed, they will be used to estimate $\mathrm{LD}_{50}$ values following World Health Organization (WHO $)^{[15]}$ guideline.

\section{Comet assay:}

The cells were treated with the extract concentration at $\mathrm{IC}_{50}$ value or at a maximum-treated concentration, in case no $\mathrm{IC}_{50}$ value was detected. After the treatment, the cells are applied on a gel-coated slide and subjected to electrophoresis and then the images were recorded. The comets in the images were observed; at least 150 cells (50 cells for each of triplicate slides) were examined for each experiment. Level of Deoxyribonucleic acid (DNA) damage was defined using the Olive Tail Moment (OTM), which is the relative amount of DNA in the tail of the comet multiplied by the median migration distance using the CASP software (Wroclaw, Poland). The nonparametric Mann-Whitney test was used for statistical analysis of the comet assay results, at $\mathrm{p}<0.05$.

\section{Biological activity testing:}

For appropriate concentration screening, rice whisky and bathroom cleaner were serially 10 -fold diluted with distilled $\mathrm{H}_{2} \mathrm{O}$ for 10 levels to get the working concentrations of $40 \%-0.00000004 \%$ (percentage of alcohol, equivalent $1000 \mu \mathrm{l} / \mathrm{ml}-0.000001 \mu \mathrm{l} / \mathrm{ml})$ and $10-0.00000001 \%$ (equivalent $100 \mu \mathrm{l} / \mathrm{ml}-0.0000001$ $\mu 1 / \mathrm{ml}$ ) for rice whisky and bathroom cleaner, respectively. The PBMCs were poisoned with each working concentration and determined for their viability by MTT assay as described above. The working concentration giving viability over $50 \%$ were selected to poison the cells in the next steps.

The combined extract was prepared by mixing the leaf powders of T. alata and T. erecta at a ratio of 1:1. Each of the $1 \mathrm{mg}$ combinations was added to $9 \mathrm{ml}$ of DMSO, stirred and kept at $-20^{\circ}$ for $2 \mathrm{~d}$. The upper part, clear solution defined as combination extract was used to test their biological activity on poisoned PBMCs by MTT and comet assays.
The poisoned PBMCs with five working concentrations of rice whisky and bathroom cleaner, 40-0.004 \% and $10 \%-0.001 \%$ were subsequently treated with the combination extract and then MTT and comet assays were performed. The control cells were the poisoned PBMCs without plant extract treatment. Biological activity was detected by comparing cell viability percentages and OTM values between the control cells and the treatments.

\section{RESULTS AND DISCUSSION}

Phytochemical investigation of the ethanol and hexane crude extracts of the two Thunbergia species, T. alata and $T$. erecta (fig. 1), which are often ornamental plants, showed several substances in the GC-MS chromatogram, as shown in Table 1 (fig. 2). The major compounds were $12.36 \%$ phytol and $46.29 \%$ oleamide in the ethanol and hexane extracts of T. alata and $24.90 \%$ phytol and $43.47 \%$ oleamide in the ethanol and hexane extracts of $T$. erecta, respectively.

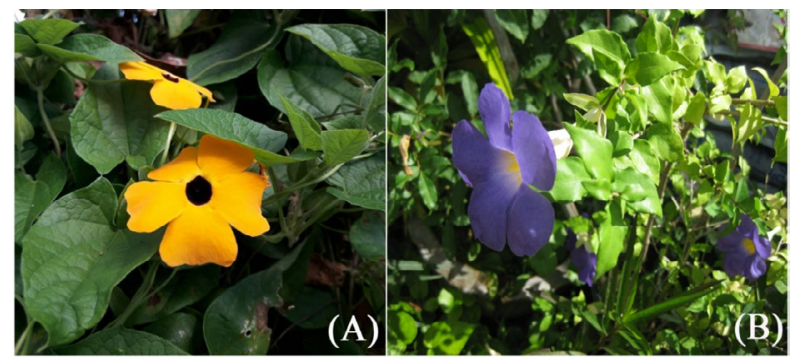

Fig. 1: The two studied plant species, (A). T. alata; (B). T. erecta

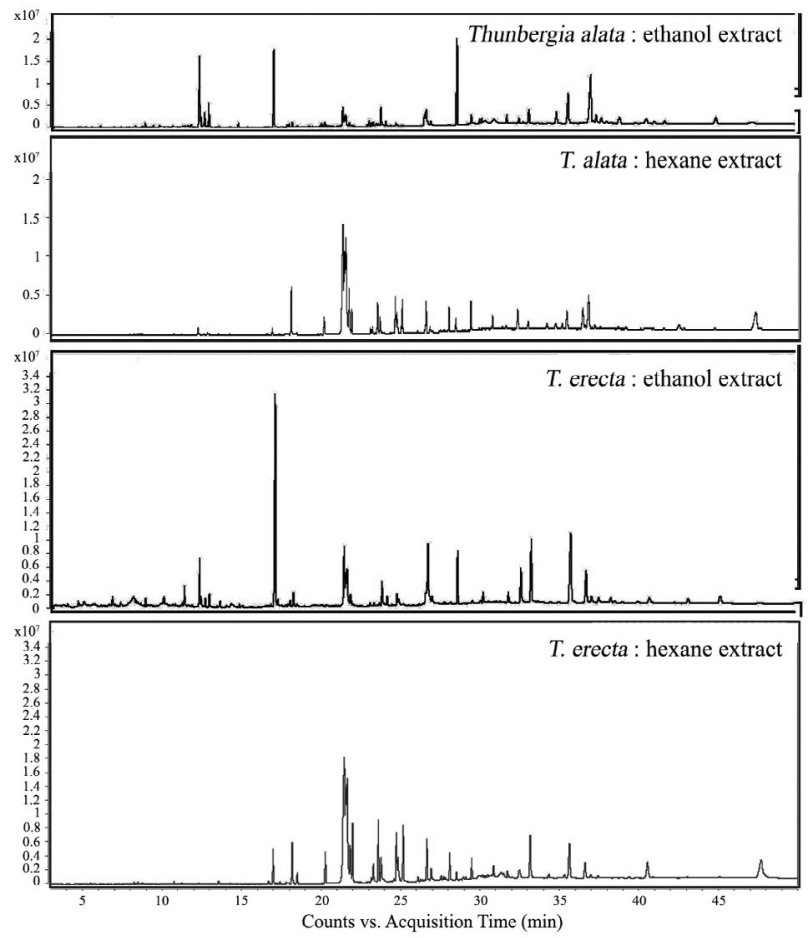

Fig. 2: Chromatograms of ethanol and hexane crude extracts from the leaves of T. alata and T. erecta by GC-MS analysis 
TABLE 1: PHYTOCHEMICAL CONSTITUENTS DERIVED FROM GC-MS OF THE TWO STUDIED LEAF EXTRACTS OF $T$. alata AND $T$. erecta BY GC-MS ANALYSIS

\begin{tabular}{|c|c|c|c|c|c|}
\hline \multirow{3}{*}{ Compounds } & \multirow{3}{*}{ Formula } & \multicolumn{4}{|c|}{ Relative content (\%) } \\
\hline & & \multicolumn{2}{|c|}{ T. alata } & \multicolumn{2}{|c|}{ T. erecta } \\
\hline & & $\mathrm{H}^{* *}$ & $\mathrm{Et}^{* *}$ & $\mathrm{H}^{* *}$ & $\mathrm{Et}^{* *}$ \\
\hline ethyl a-d-glucopyranoside & $\mathrm{C}_{8} \mathrm{H}_{16} \mathrm{O}$ & - & - & - & 0.75 \\
\hline oxazole, 5-hexyl-2,4-dimethyl- & $\mathrm{C}_{11} \mathrm{H}_{19} \mathrm{NO}$ & - & - & - & 1.15 \\
\hline phytol, acetate & $\mathrm{C}_{22} \mathrm{H}_{42} \mathrm{O}_{2}$ & - & 9.59 & - & 3.20 \\
\hline (2E)-3,7,11,15-tetramethyl-2-hexadecene & $\mathrm{C}_{20} \mathrm{H}_{40}$ & - & 1.14 & - & 0.37 \\
\hline 3,7,11,15-tetramethyl-2-hexadecen-1-ol & $\mathrm{C}_{20} \mathrm{H}_{40} \mathrm{O}$ & 0.15 & 4.83 & - & 1.50 \\
\hline hexadecanoic acid, ethyl ester & $\mathrm{C}_{16} \mathrm{H}_{32} \mathrm{O}_{2}$ & - & 0.49 & - & 0.30 \\
\hline phytol & $\mathrm{C}_{20} \mathrm{H}_{40} \mathrm{O}$ & 0.48 & 12.36 & 2.46 & 24.90 \\
\hline methyl stearate & $\mathrm{C}_{19} \mathrm{H}_{38} \mathrm{O}_{2}$ & - & - & - & 0.39 \\
\hline ethyl $9,12,15$-octadecatrienoate & $\mathrm{C}_{20} \mathrm{H}_{34} \mathrm{O}_{2}$ & - & 0.47 & - & - \\
\hline hexadecanamide & $\mathrm{C}_{16} \mathrm{H}_{33} \mathrm{NO}$ & 4.47 & 0.61 & 3.35 & 1.24 \\
\hline docosane & $\mathrm{C}_{22} \mathrm{H}_{46}$ & - & - & 0.72 & - \\
\hline octadecanoic acid, ethyl ester & $\mathrm{C}_{20} \mathrm{H}_{40} \mathrm{O}_{2}$ & - & 0.16 & - & - \\
\hline (Z)-9-octadecenamide (oleamide) & $\mathrm{C}_{18} \mathrm{H}_{35} \mathrm{NO}$ & 46.29 & 7.47 & 43.47 & 13.38 \\
\hline octadecanamide & $\mathrm{C}_{18} \mathrm{H}_{37} \mathrm{NO}$ & 4.73 & 0.49 & 2.43 & 0.79 \\
\hline tetracosane & $\mathrm{C}_{24} \mathrm{H}_{50}$ & - & - & 4.27 & - \\
\hline glycerol B-palmitate & $\mathrm{C}_{19} \mathrm{H}_{38} \mathrm{O}_{4}$ & 1.33 & 2.68 & 1.86 & 2.03 \\
\hline lidocaine benzyl benzoate & $\mathrm{C}_{28} \mathrm{H}_{34} \mathrm{~N}_{2} \mathrm{O}_{3}$ & - & 0.66 & - & - \\
\hline benzyldiethyl-(2,6-xylylcarbamoylmethyl)-ammonium benzoate & $\mathrm{C}_{28} \mathrm{H}_{34} \mathrm{~N}_{2} \mathrm{O}_{3}$ & - & - & - & 0.74 \\
\hline cis-11-Eicosenamide & $\mathrm{C}_{20} \mathrm{H}_{39} \mathrm{NO}$ & 5.50 & & 6.18 & 0.99 \\
\hline glycerin 1-monostearate & $\mathrm{C}_{21} \mathrm{H}_{24} \mathrm{O}_{4}$ & 0.46 & 0.43 & 0.95 & 0.49 \\
\hline squalene & $\mathrm{C}_{30} \mathrm{H}_{50}$ & 0.91 & 13.82 & 0.53 & 4.34 \\
\hline $\begin{array}{l}\text { oxirane, 2,2-dimethyl-3-(3,7,12,16,20-pentamethyl-3,7,11,15,19- } \\
\text { heneicosapentaenyl)-, (all-E)- }\end{array}$ & $\mathrm{C}_{30} \mathrm{H}_{50}$ & - & - & - & 0.91 \\
\hline$\gamma$-tocopherol & $\mathrm{C}_{28} \mathrm{H}_{48} \mathrm{O}_{2}$ & - & 1.08 & 0.56 & 0.93 \\
\hline dl-a-tocopherol & $\mathrm{C}_{29} \mathrm{H}_{50} \mathrm{O}_{2}$ & 0.74 & 2.82 & 4.73 & 8.16 \\
\hline campesterol & $\mathrm{C}_{28} \mathrm{H}_{48} \mathrm{O}$ & 0.79 & 2.91 & - & - \\
\hline stigmasterol & $\mathrm{C}_{29} \mathrm{H}_{48} \mathrm{O}$ & 2.50 & 8.03 & 7.13 & 16.74 \\
\hline$\gamma$-sitosterol & $\mathrm{C}_{29} \mathrm{H}_{50} \mathrm{O}$ & 5.88 & 16.60 & 0.38 & 0.87 \\
\hline stigmasta-5,24(28)-dien-3-ol, (3B,24Z)- & $\mathrm{C}_{29} \mathrm{H}_{48} \mathrm{O}$ & - & 1.51 & - & 0.75 \\
\hline B-amyrin & $\mathrm{C}_{30} \mathrm{H}_{50} \mathrm{O}$ & - & 1.12 & - & - \\
\hline a-amyrin & $\mathrm{C}_{30} \mathrm{H}_{50} \mathrm{O}$ & - & 2.14 & - & - \\
\hline vitamin $\mathrm{E}^{*}$ & $\mathrm{n} / \mathrm{a}$ & - & - & - & 1.20 \\
\hline friedelan-3-one & $\mathrm{C}_{30} \mathrm{H}_{50} \mathrm{O}$ & - & - & - & 0.86 \\
\hline unknown & & 25.77 & 8.59 & 20.99 & 13.00 \\
\hline
\end{tabular}

*Vitamin E refers to a class of compounds; n/a: not analyzed as individual compound by the Wiley $7 \mathrm{~N} .1$ library, ${ }^{*} \mathrm{H}=\mathrm{Hexane}$, Et=Ethanol

The primary (maximum) mass concentrations of the crude ethanol and hexane extracts of the two studied species were 0.5 and $0.7 \mathrm{mg} / \mathrm{ml}$ for T. alata and 0.7 and $0.7 \mathrm{mg} / \mathrm{ml}$ for $T$. erecta, respectively. The extracts were subjected to serial 10 -fold dilutions and used for the MTT assay (Table 2). The results showed no $\mathrm{IC}_{50}$ values and there was no toxicity at the cellular level, with high percentages of cell viability revealed in the plotted graph between extract concentration and cell viability percentages (fig. 3). The cell viability percentages were
$72.40 \pm 0.16-76.13 \pm 0.17$ and $65.57 \pm 0.13-74.05 \pm 0.16$ with the ethanol and hexane extracts of $T$. alata and $55.70 \pm 0.21-88.83 \pm 0.27$ and $76.58 \pm 0.26-83.43 \pm 0.25$ with the ethanol and hexane extracts of $T$. erecta, respectively.

Because the extracts did not show $\mathrm{IC}_{50}$ values, the concentration of the first extract dilution was used as working the concentration (Table 3) and selected for further genotoxicity study via the comet assay. The results showed that the extracts of both sample species 
induced significant DNA damage in PBMCs $(p<0.05)$ compared to the negative control. The level of DNA damage exhibited OTM in PBMCs (Table 3, fig. 4).

Biological activity testing was performed, which included poison concentration screening for use in the test and preparing controls for experiments to compare via MTT and comet assays. The concentrations of poison, rice whisky and bathroom cleaner, were screened using the MTT method. The results (Table 4, fig. 5), the concentrations of them were selected from the first to fifth as $40 \%-0.04 \%$ and $10 \%-0.001 \%$ and the cell viability percentages were $56.26 \pm 0.12$ $62.05 \pm 0.12$ and $45.82 \pm 0.14-56.33 \pm 0.17$ for the rice whisky and bathroom cleaner, respectively. A set of controls (PBMCs incubated with each poison), which was simultaneously analyzed with the treatments, was prepared using the same set of PBMCs as the treatments. After the experiments, the final activity results were obtained by comparing the MTT results with the cell viability percentages and the comet

TABLE 2: WORKING EXTRACT CONCENTRATIONS FROM ETHANOL AND HEXANE EXTRACTS OF $T$. alata AND T. erecta LEAVES DILUTED AND USED FOR MTT ASSAY SHOWING CELL VIABILITY PERCENTAGES

\begin{tabular}{lcccc}
\hline Plant & Extraction solvent & Working extract conc. $(\mathrm{mg} / \mathrm{ml})$ & $\mathrm{IC}_{50}(\mathrm{mg} / \mathrm{ml})$ & Cell viability $(\%)$ \\
\hline \multirow{2}{*}{ T. alata } & Hexane & $0.07-0.000007$ & - & $65.57 \pm 0.13-74.05 \pm 0.16$ \\
& Ethanol & $0.05-000005$ & - & $72.40 \pm 0.16-76.13 \pm 0.17$ \\
\multirow{2}{*}{ T. erecta } & Hexane & $0.07-0.000007$ & - & $76.58 \pm 0.26-83.43 \pm 0.25$ \\
& Ethanol & $0.07-0.000007$ & - & $55.70 \pm 0.21-88.83 \pm 0.27$ \\
\hline
\end{tabular}

TABLE 3: THE LEVEL OF DNA DAMAGE EXPRESSED AS OLIVE TAIL MOMENT (OTM) IN PBMCS AFTER TREATMENT WITH ETHANOL AND HEXANE EXTRACTS OF $T$. alata AND $T$. erecta LEAVES

\begin{tabular}{lcccc}
\hline Plants & Extraction Solvent & Working extract conc. $(\mathrm{mg} / \mathrm{ml})$ & Olive Tail Moment (OTM) & P value \\
\hline \multirow{3}{*}{ T. alata } & hexane & 0.07 & $1.07 \pm 0.82$ & $<0.0001$ \\
& ethanol & 0.05 & $1.04 \pm 0.45$ & $<0.0001$ \\
& negative control & - & $0.05 \pm 0.03$ & - \\
T. erecta & hexane & 0.07 & $0.14 \pm 0.11$ & 0.0020 \\
& ethanol & 0.07 & $0.30 \pm 0.14$ & $<0.0001$ \\
\hline
\end{tabular}

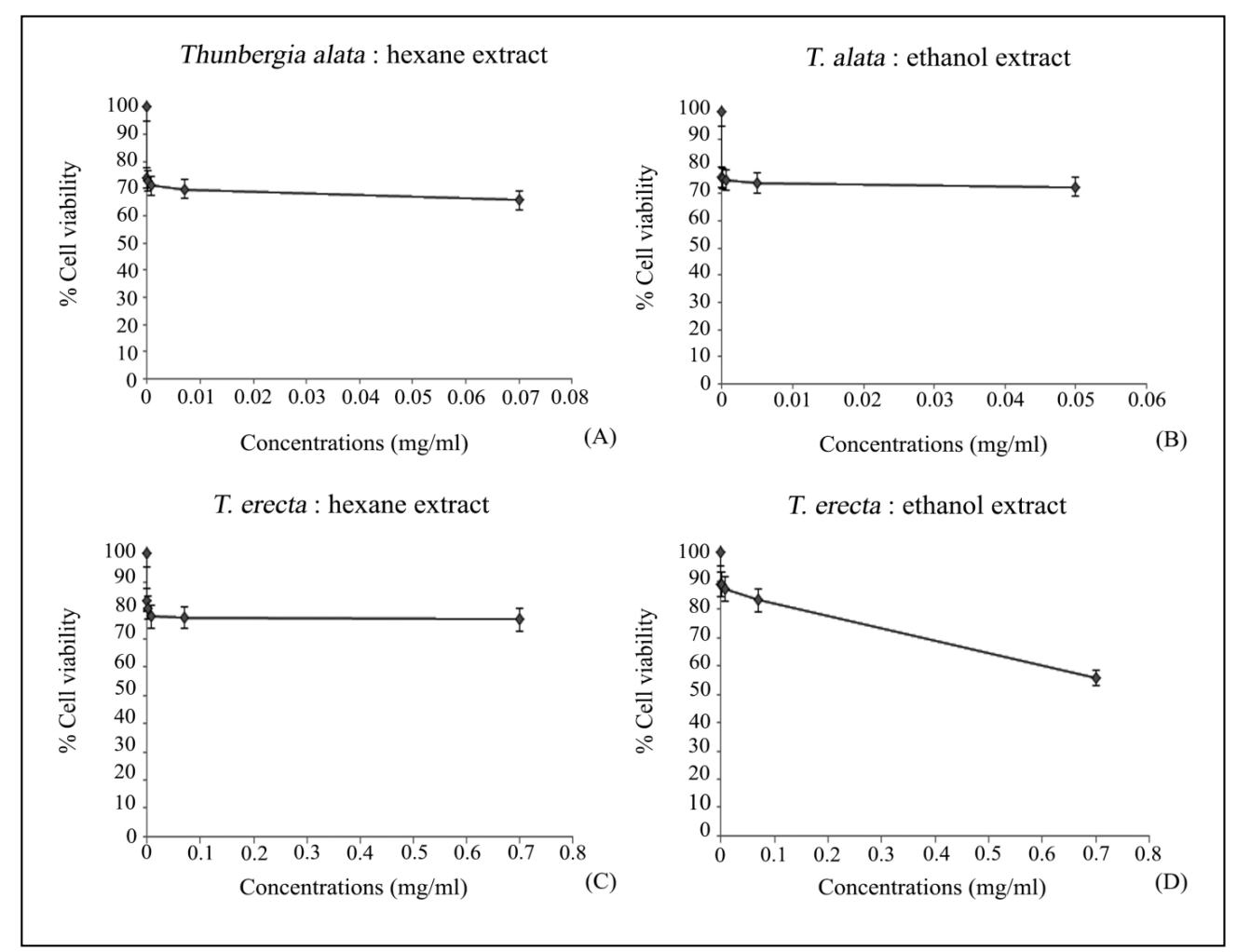

Fig. 3: Graphs between extract concentrations and cell viability percentages resulting from MTT assay of $T$. alata and $T$. erecta leaf extracts 
TABLE 4: POISON CONCENTRATION SCREENING, RICE WHISKY AND BATHROOM CLEANER, INDICATED BY CELL VIABILITY PERCENTAGES

\begin{tabular}{lccc}
\hline Concentration of rice whiskey (\%) & Cell viability (\%) & Concentration of bathroom cleaner (\%) & Cell viability (\%) \\
\hline 40 & $56.26 \pm 0.12$ & 10 & $45.82 \pm 0.14$ \\
4.0 & $59.10 \pm 0.12$ & 1.0 & $48.42 \pm 0.18$ \\
0.4 & $60.74 \pm 0.12$ & 0.1 & $53.74 \pm 0.17$ \\
0.04 & $61.04 \pm 0.12$ & 0.01 & $54.09 \pm 0.18$ \\
0.004 & $62.05 \pm 0.12$ & 0.001 & $56.33 \pm 0.17$ \\
0.0004 & $63.21 \pm 0.12$ & 0.0001 & $57.37 \pm 0.17$ \\
0.00004 & $64.85 \pm 0.13$ & 0.00001 & $62.49 \pm 0.17$ \\
0.000004 & $65.93 \pm 0.13$ & 0.000001 & $65.61 \pm 0.17$ \\
0.000004 & $66.64 \pm 0.13$ & 0.0000001 & $67.98 \pm 0.18$ \\
0.00000004 & $67.74 \pm 0.14$ & 0.00000001 & $69.44 \pm 0.18$
\end{tabular}

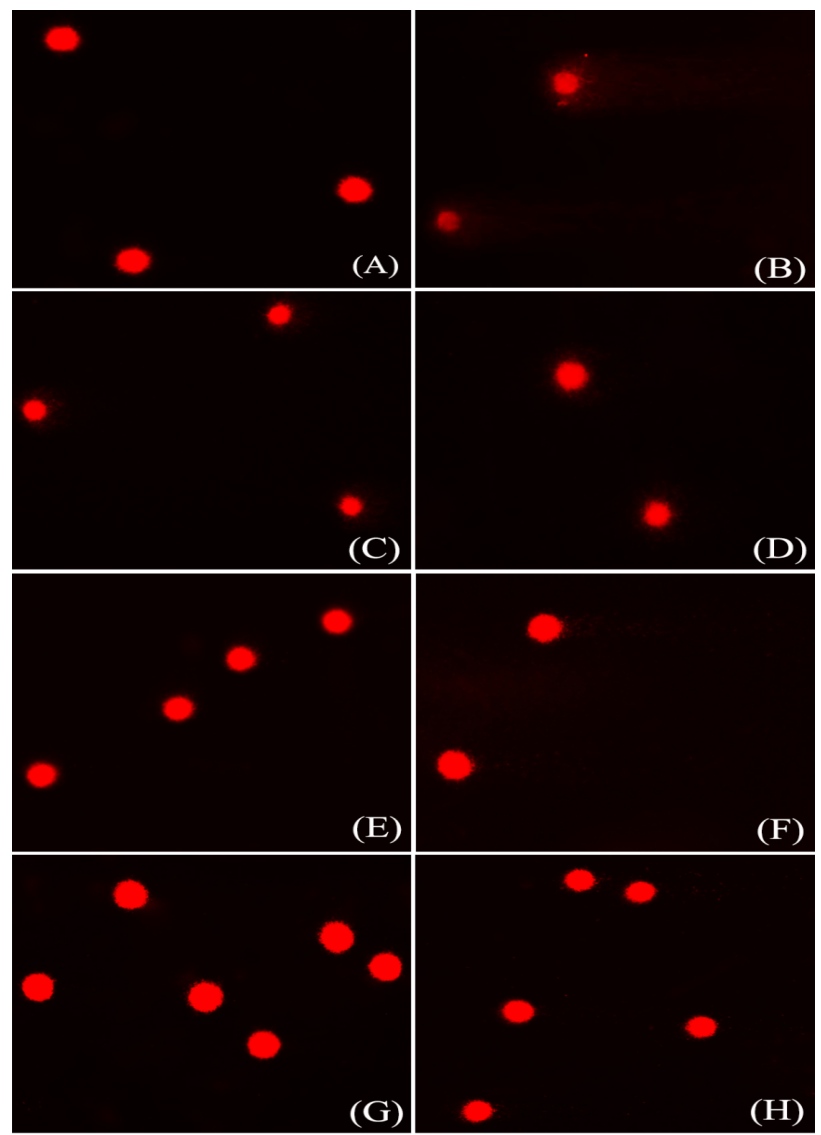

Fig. 4: Comet assay images of PBMCs (200X); (A) negative control for T. alata; (B) positive control for T. Alata; (C) hexane T. alata leaf extract; (D) ethanol T. alata leaf extract; (E) negative control for T. erecta; (F) positive control for T. erecta; (G) hexane T. erecta leaf extract; (H) ethanol T. erecta leaf extract
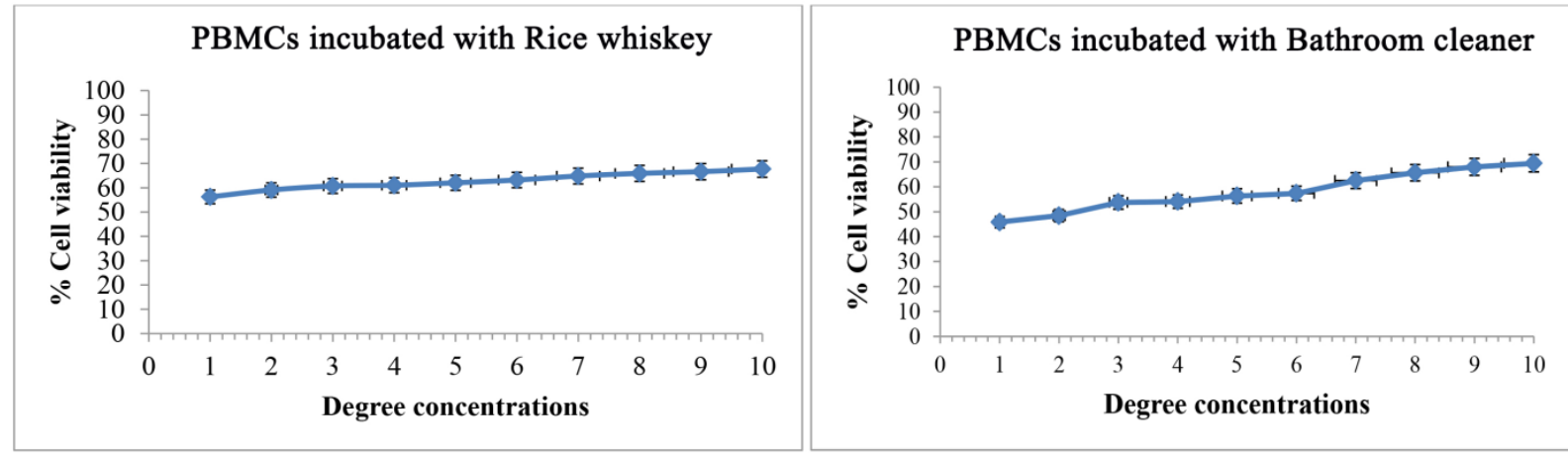

Fig. 5: Graphs of poison concentration screening showing relations between 10 level concentrations of bathroom cleaner and rice whiskey showing cell viability percentages 
result with the OTM values of the control and the treatments. These treatments (poisoned PBMCs treated with extracts) had higher cell viability percentages $(65.67 \pm 0.76-84.49 \pm 0.54,68.17 \pm 0.21-80.96 \pm 0.22$ and $63.34 \pm 0.54-78.63 \pm 0.52$ for rice whiskey; $44.09 \pm 0.69$ $75.39 \pm 0.62,36.34 \pm 0.12-72.79 \pm 0.14$ and $53.63 \pm 0.41-$ $72.36 \pm 0.38$ for bathroom cleaner with the $T$. alata, $T$. erecta and combined extracts, respectively) than the controls $(62.54 \pm 0.20-74.51 \pm 0.19)$ (Table 5, fig. 6). The combination did not show higher cell viability percentages than the two studied species.
Similarly, OTM values of the treatments, which were $0.046 \pm 0.045,0.047 \pm 0.041,0.055 \pm 0.038$ for rice whisky (Table 5, fig. 7) and $0.47 \pm 0.34,0.55 \pm 0.47,0.58 \pm 0.42$ for bathroom cleaner (Table 5, fig. 8) with the T. alata, $T$. erecta and combined extracts, respectively, were clearly shorter than the OTM values of the controls, $3.77 \pm 1.97$. The combined extract also did not show shorter OTM values than the other two studied species, meaning that it was not better. The shorter OTM values indicate less DNA damage than the other OTM values.

TABLE 5: THE DETOXIFYING BIOACTIVITY RESULTS INDICATED BY CELL VIABILITY PERCENTAGES AND OLIVE TAIL MOMENT (OTM) FROM THE POISONS RICE WHISKY AND BATHROOM CLEANER IN PBMCS TREATED WITH THE $T$. alata, $T$. erecta AND COMBINED EXTRACTS

\begin{tabular}{lcccc}
\hline \multirow{2}{*}{ Experiment } & \multicolumn{2}{c}{ Rice whiskey } & \multicolumn{2}{c}{ Bathroom cleaner } \\
\cline { 2 - 6 } Controls & $62.54 \pm 0.20-74.51 \pm 0.19$ & $3.600 \pm 1.970$ & $29.48 \pm 0.14-67.30 \pm 0.17$ & $3.770 \pm 1.970$ \\
$T$. alata & $65.67 \pm 0.76-84.49 \pm 0.54$ & $0.046 \pm 0.045$ & $44.09 \pm 0.69-75.39 \pm 0.62$ & $0.47 \pm 0.34$ \\
$T$. erecta & $68.17 \pm 0.21-80.96 \pm 0.22$ & $0.047 \pm 0.041$ & $36.34 \pm 0.12-72.79 \pm 0.14$ & $0.55 \pm 0.47$ \\
Combination & $63.34 \pm 0.54-78.63 \pm 0.52$ & $0.055 \pm 0.046$ & $53.63 \pm 0.41-72.36 \pm 0.38$ & $0.58 \pm 0.42$ \\
\hline
\end{tabular}

Thunbergia alata : rice whiskey

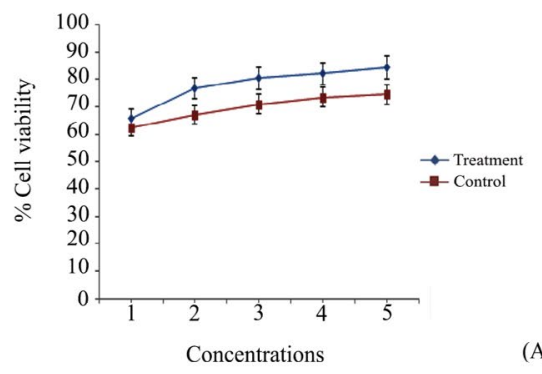

$T$. erecta : rice whiskey

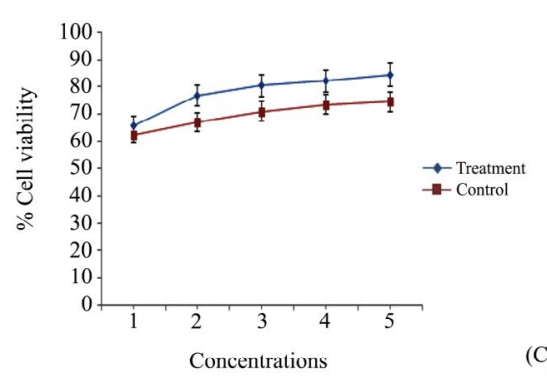

Combination : rice whiskey

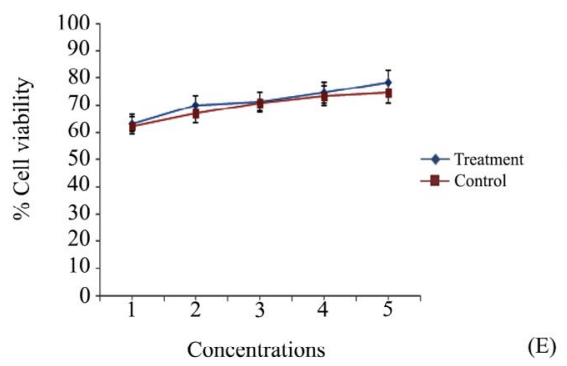

T. alata : bathroom cleaner

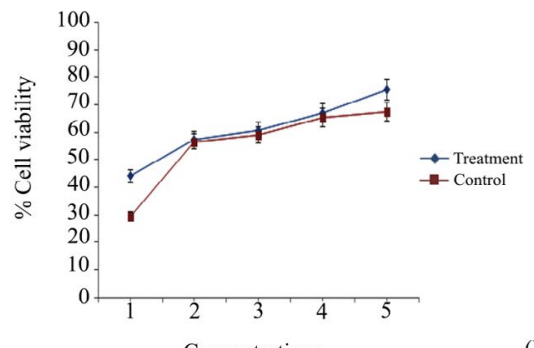

(B)

T. erecta : bathroom cleaner

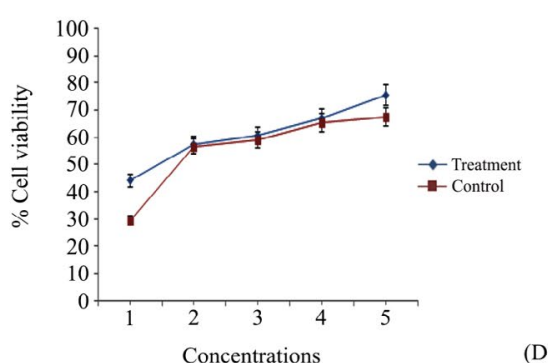

(D)

Combination : bathroom cleaner

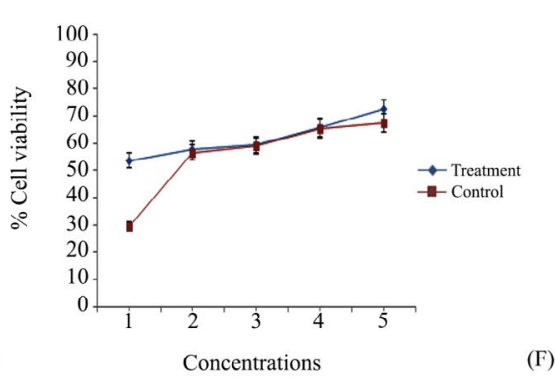

(F)

Fig. 6: Graphs plotted between poisoned concentrations (rice whiskey, left; bathroom cleaner, right) and cell viability of the controls in red lines (poisoned PBMCs) and the treatments in blue lines (poisoned PBMCs treated with T. alata and T. erecta leaf extracts) indicating the detoxifying bioactivity results by cell viability percentages 

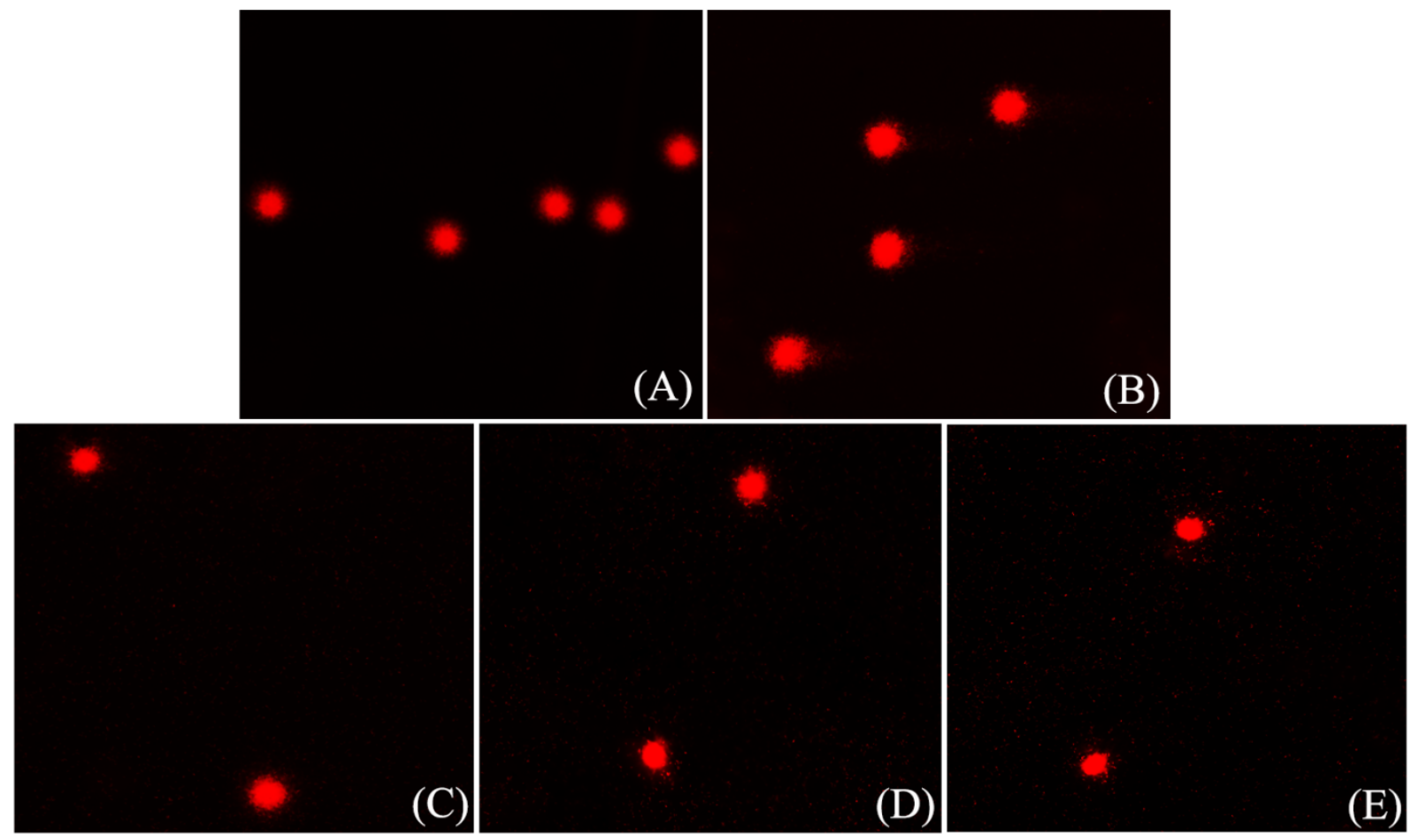

Fig. 7: Comet assay images of rice whisky-poisoned PBMCs (200×); (A) negative control; (B) the control; (C) treatment of T. alata leaf extract; (D) treatment of $T$. erecta leaf extract; (E) treatment of the combined extract
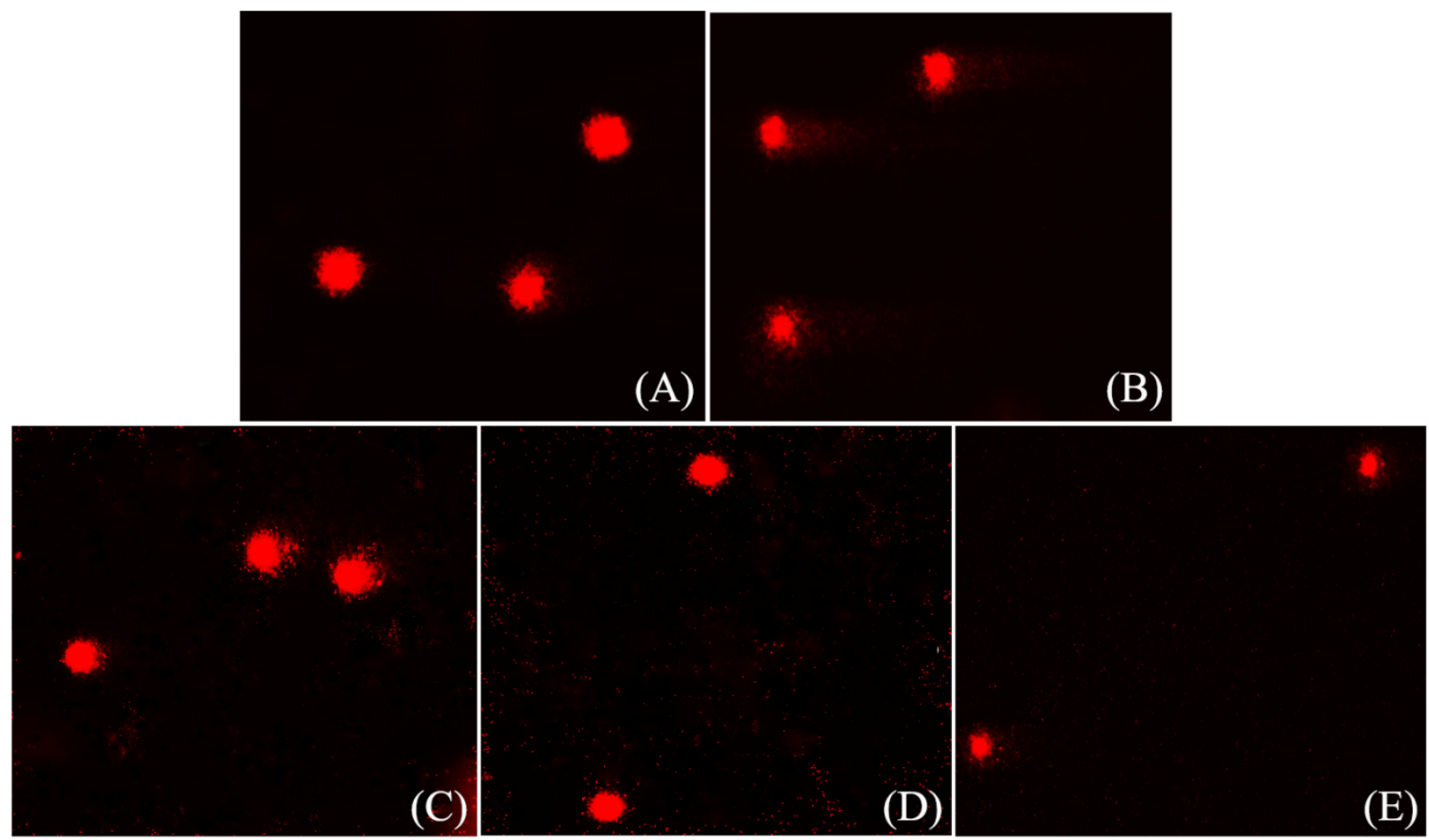

Fig. 8: Comet assay images of bathroom cleaner-poisoned PBMCs (200×); (A) negative control; (B) positive control; (C) treatment of $T$. alata leaf extract; (D) treatment of $T$. erecta leaf extract; (E) treatment of the combined extract

Testing in both the normal and poisoned human PBMCs is in preclinical trials with animal cell and tissue culture following Doke and Dhawale ${ }^{[16]}$ and the Physicians Committee for Responsible Medicine ${ }^{[17]}$. The methods selected here are reliable for in vitro and human cell and tissue, PBMCs cultures for cytotoxicity and genotoxicity with MTT and comet assays for toxicity and biological activity testing.

The two studied species and the combination showed no toxicity at the cellular level, but they induced significant DNA damage at the concentrations tested, 0.05 and $0.07 \mathrm{mg} / \mathrm{ml}$. It means that genetic materials 
of the cells were destructed, can lead mutation. These two extract concentration levels may be carcinogen ${ }^{[18]}$. So, the hazardous level must be found for consumption caution of these two plants, the tested concentrations which induced significant DNA damage, 0.05 and $0.07 \mathrm{mg} / \mathrm{ml}$ were used for $\mathrm{LD}_{50}$ calculation for consumption limitation. The $\mathrm{LD}_{50}$ values were 452.915 and $513.306 \mathrm{mg}$ for the extracts of T. alata and T. erecta, respectively per $1 \mathrm{~kg}$ rat, which are classified in the $\mathrm{WHO}^{[15]}$ class II, moderately hazardous when taken orally by rat at $50-2000 \mathrm{mg} / \mathrm{kg}$ body weight. When passed through humans at approximately $50 \mathrm{~kg}$ of body weight, the plants can be taken up to 2500-100000 $\mathrm{mg}(2.5-100 \mathrm{~g})$ to reach a moderate hazard according to the $\mathrm{WHO}^{[15]}$ referring that doses of $T$. alata and T. erecta extracts under 2.5-100 g, should be saved for consumers. Concerning these data, usages of $T$. erecta reported ${ }^{[11-13,19]}$ in cooking, eating as a vegetable and application of its leaves for a remedy of headache, should be carefully determined for the doses. However, it is not surprise that $T$. alata leaf extracts can have activity against Pseudomonas aeruginosa and have significant antibacterial activity against Salmonella typhi ${ }^{[20]}$, according to their biological activities including DNA damage in normal and poisoned PBMCs, which can be assumed to occur at plant concentrations.

At careful extracts doses, the presence of phytochemicals needs to be further considered for bioactivity assessments for further use in humans. The high quantity of oleamide and phytol were probable major or worked together having synergetic activity; phytol made up $12.36 \%$ and $24.90 \%$ in $T$. alata and $T$. erecta, while oleamide made up $46.29 \%$ and $43.47 \%$ in $T$. alata and $T$. erecta, respectively. Therefore, the extracts should have activities against scopolamineinduced memory loss, increase the production of the hormone acetylcholine, increasing memory function and act as a chemopreventive agent against Alzheimer's disease, inducing deep sleep and upregulating appetite $^{[21,22]}$. Additionally, the presence of phytol can be assumed as a property of plants. Phytol is derived from chlorophyll metabolism and released when plants are digested in the intestines. It is indispensable in the human body as it has important functions, including regulating blood glucose by activating enzymes that have a positive effect on the production of insulin and it may restore the metabolic functions of patients with type 2 diabetes, reducing cholesterol levels in blood, ultimately reducing blood pressure levels ${ }^{[23]}$. Moreover, phytol leads to the biosynthesis of tocopherols, a type of vitamin $\mathrm{E}^{[24]}$ which is useful for cell health and can help decrease cell aging ${ }^{[25]}$. Therefore, the two studied plants, which can be assumed to be beneficial in human health, should be focused on the correct doses. Another minor substance may potentially work together with the major phytochemicals based on experiments at the preclinical trial level here.

As some synthetic drugs display several limitations, including side effects and costs, medicinal plants and their phytochemical compounds have been considered and used for many disease treatments in fresh, dried, and prepared forms, including T. alata and T. erecta. However, the dose limitations have been focused on.

\section{Acknowledgements:}

This research is financially supported by Research and Academic Services, Khon Kaen University.

\section{Conflict of interest:}

Authors have no conflict of interest.

\section{REFERENCES}

1. Kosai P, Jiraungkooskul K, Jiraungkooskul W. Review of antidiabetic activity of "Rang Jeud" Thunbergia laurifolia. J Appl Pharm Sci 2015;5(2):99-103.

2. Junsi M, Siripongvutikorn S. Thunbergia laurifolia, a traditional herbal tea of Thailand: botanical, chemical composition, biological properties and processing influence. Int Food Res J 2016;23(3):923-7.

3. Phyu MP, Tangpong J. Protective effect of Thunbergia laurifolia (Linn.) on lead induced acetylcholinesterase dysfunction and cognitive impairment in mice. Biomed Res Int 2013;2013.

4. Ruangyuttikarn W, Chattaviriya P, Morkmek N, Chuncharunee $\mathrm{S}$, Lertprasertsuke N. Thunbergia laurifolia leaf extract mitigates cadmium toxicity in rats. Sci Asia 2013;39:19-25.

5. Chivapat S, Chvalittumrong $\mathrm{P}$, Attawish A, Bansiddhi J, Padungpat S. Chronic toxicity of Thunbergia laurifolia Lindl. extract. J Thai Trad Alt Med 2009;7(1):17-24.

6. Uddin J, Ala MN, Biswas, K, Rahman A. In vitro antioxidative and cholinesterase inhibitory properties of Thunbergia grandiflora leaf extract. Cogent Food Agric 2016;2(1):1256929.

7. Ibrahim MT, El wafa SAA, Sleem AA. Phytochemical and biological investigation of Thunbergia grandiflora. J Pharmacogn Phytochem 2017;6(2):43-51.

8. Cho YC, Kim YR, Kim BR, Cho S. Thunbergia alata inhibits inflammatory responses through the inactivation of ERK and STAT3 in macrophages. Int J Mol Med 2016;38(5):1596-604.

9. Housti F, Andary C, Gargadennec A, Amssa M. Effects of wounding and salicylic acid on hydroxycinnamoyl malic acids in Thunbergia alata. Plant Physiol Biochem 2002;40(9):761-9.

10. Tukiran, Wardana AP. Thunbergia erecta L. flower as an alternative acid base natural indicator. Rasayan $\mathrm{J}$ Chem 2018;11(2):773-9.

11. Manokari M, Shekhawat MS. Biosynthesis and characterization of zinc oxide nanoparticles using Thunbergia erecta (Benth.) T. Anders plant extracts. Arch Agr Environ Sci 2017;2(3):148- 
51.

12. Bhuiyan MR, Nahar UJ, Begum A. Evaluation of hypoglycemic effect of extracts from derris scandens and Thunbergia erecta leaves in Swiss albino mice. Research J Pharm Tech 2019;12(7):3467-70.

13. Begum A, Hossen A, Moly AA, Bhuiyan MM, Shahed-Al MS. In vivo sedative and anxiolytic activities of Thunbergia erecta (Acanthaceae) leaves activate gamma-aminobutyric acid (GABA) mediated hyperpolarization in Swiss albino mice. Pharmacol Pharm 2019;10(4):177-93.

14. Sirikhansaeng P, Tanee T, Sudmoon R, Chaveerach A. Major phytochemical as $\gamma$-sitosterol disclosing and toxicity testing in Lagerstroemia species. Evid Based Complement Alternat Med 2017;2017.

15. World Health Organization. The WHO recommended classification of pesticides by hazard and guidelines to classification; 2009.

16. Doke SK, Dhawale SC. Alternatives to animal testing: a review. Saudi Pharm J 2015;23(3):223-9.

17. Physicians Committee for Responsible Medicine. Problems Associated with Animal Experimentation; 2013. Wisconsin, Washington DC.

18. Savale SK. Genotoxicity of drugs: introduction, prediction and evaluation. Asian J Biomaterial Res 2018;4(6):1-29.

19. Tropical Plants Database. Useful tropical plants: Thunbergia alata; 2019.

20. Jenifer S, Priya S, Laveena DK, Singh SJS, Jeyasree J. Sensitivity patterns of some flowering plants against Salmonella typhi and Pseudomonas aeruginosa. World J Pharm Pharm Sci 2014;3(12):1212-20.

21. Hachisu M, Konishi K, Hosoi M, Tani M, Tomioka H, Inamoto A, et al. Beyond the hypothesis of serum anticholinergic activity in Alzheimer's disease: acetylcholine neuronal activity modulates brain-derived neurotrophic factor production and inflammation in the brain. Neurodegener Dis 2015;15(3):1827.

22. Thooptianrat T, Chaveerach A, Sudmoon R, Tanee T, Liehr $\mathrm{T}$, Babayan N. Screening of phytochemicals and toxicity of medicinal plants, Dillenia species. J Food Biochem 2017;41(3):1-9.

23. Yoshikawa T. Food Factors for Health Promotion. $61^{\text {st }}$ ed. Karger Publishers, Kyoto; 2009.

24. Mach J. Phytol from degradation of chlorophyll feeds biosynthesis of tocopherols. Plant Cell 2015;27:2676.

25. Netscher T. Synthesis of vitamin E. Vitam Horm 2007;76:155202. 